\title{
VORWORT.
}

Die vorliegende Übersetzung, ist durch eine Reihe von Zusätzen bereichert, welche Herr Dr. Francotre die Güte hatte mir mitzuteilen. Auch der Unterzeichnete hat einige Anmerkungen zugefügt, die zumeist auf die im Königreich Sachsen herrschende Epidemie Bezug nehmen; dieselben sind überall durch ein beigefügtes $\mathrm{S}$. besonders kenntlich gemacht. Die Zusätze des Herrn Dr. Francotte verleihen der Übersetzung einen selbständigen Wert neben dem Original; diejenigen des Übersetzers dürften vielen Lesern nicht ganz unwillkommen sein.

Dresden, im September 1885.

\section{Dr. Spengler,}


